\title{
Resist or Adapt? A Narrative Analysis of Endeavors for Belonging Among Young Adults with Co-Occurring Substance Use and Mental Health Problems
}

\author{
Randi Semb $\mathbb{D} \cdot$ Knut Tore Sælør $\cdot$ Marit Borg
}

Received: 19 January 2021 / Accepted: 28 May 2021 / Published online: 21 June 2021

(C) The Author(s) 2021

\begin{abstract}
The article explores how young adults with co-occurring substance use and mental health problems experience and describe their own and others' contributions to their sense of community belonging. This article is part of a larger qualitative interview study of young adults. The data for this report were the individual interviews with two study participants. These participants were chosen because they offered in-depth understandings relating to various aspects of community belonging. A thematic narrative analysis of the interview data was carried out. Central to this model of analysis is to transform unstructured qualitative interview data into a unified narrative for each participant, structured around a thematic plot. The analysis revealed two plots: 'Having to go against yourself to be an insider', and 'You have to realize that you have problems and try to do something about them'. We interpreted the first narrative as an expression of marginalized people feeling they deserve recognition from society, while the second narrative reflected the idea that each person has a personal responsibility for being valued. We conclude that the narratives expressed the importance of helping young adults to place their lived experiences in a larger social context.
\end{abstract}

R. Semb $(\bowtie) \cdot$ K. T. Sælør · M. Borg

Centre for Mental Health and Substance Abuse, Faculty of

Health and Social Sciences, University of Southeast

Norway, Drammen, Norway

e-mail: randi.semb@usn.no
Keywords Belonging - Agency · Young adults · Substance use $\cdot$ Mental health

\section{Introduction}

A sense of community belonging is often taken for granted because people living their ordinary, everyday lives do not question belongingness unless they experience negative reactions in their social interactions [1]. Often, it is the lack of belonging that one notices: that is alienation and the feeling that oneself does not matter. The present study is about young adults with co-occurring substance use and mental health-related problems (co-occurring problems). They are citizens typically associated with social exclusion, who are struggling for belonging.

Co-occurring problems are complex biopsychosocial phenomena, with different degrees of severity and influence on people's lives. Different terms are used to denote these problems [2-4]. Clinical studies and guidelines often use specific psychiatric diagnoses when defining co-occurring problems $[3,5]$. In the present study the problems also include non-diagnosed problems.

Studies where people with co-occurring problems are the target group generally have a clinical focus. However, in recent years some studies with a recovery perspective have explored different aspects of 
everyday life $[6,7]$. Only a few of these deal with young adults $[8,9]$. In the present study the everyday focus is reflected in how the young adults' meeting with their local community and broader society is part of their experience and understanding of how they can manage to belong to the community with or without their co-occurring problems.

An important theme for many young adult citizens is to find their place in society $[10,11]$. An experience of 'being normal' can be of particular importance in this phase of life [8]. However, research related to young adults with co-occurring problems shows that they are at risk of experiencing outsiderness $[4,12,13]$. The group is often associated with various forms of deviations related to psychosocial situations in childhood and adolescence [13-16], and with low participation in education, work, and other valued activities $[12,14]$. The terms 'exclusion' and 'inclusion' are used to denote 'objective' measures of membership and participation in 'ordinary' activities as well as subjective dimensions of quality and meaning of life in society [17]. The term 'sense of belonging', however, emphasizes the subjective dimensions [18]. 'Sense of community belonging' is exclusively a 'bottom-up' perspective on social inclusion, unlike 'top-down' perspectives of government policies and dominant discourses in society related to the 'ideal' citizen. Such a perspective on social inclusion is rarely used in studies targeting these groups of young people [4, 14]. In one study, of which this study is an extension, young adults with cooccurring problems seemed to take for granted that they would need to change and adapt their lives to be accepted as 'proper' citizens [13]. There were different opinions as to whether this was the right thing to do.

It can be easier to promote a sense of belonging to the community before the young adults are further marginalized. Persons with co-occurring problems are described as difficult to help because of their complex problems [2, 19]. Service providers characterize young adults as unmotivated to receive services. In order to reach out to this group it can be of crucial importance that service providers take into account issues that they emphasize themselves [20,21].

Promoting community belonging involves changing either the person or the community. Pragmatism and moral concerns may guide the understanding of how this can take place. Young people report varying degrees of guilt and responsibility for their lack of community belonging [13]. Because young adults with co-occurring problems often experience outsiderness, an important topic is how to improve their capacity to achieve a sense of community belonging. How the young adults understand this moral issue is of importance in terms of the support they consider relevant to increase their ability to achieve community belonging. In this article, we aimed to gain deeper insight regarding this. The research question was: How do young adults with co-occurring problems experience and describe their own and others' responsibilities for achieving a sense of belonging to the community?

Capacity to Achieve a Sense of Community Belonging

A sense of community belonging is an expression of the mutual dependence between a person and society [1]. Hagerty and colleagues pointed at two central characteristics connected with experiences of belonging: one relating to the experience of being valued (i.e., worth something) and the other relating to the concept of 'fitting into' something important to oneself [18]. The extent to which it is possible to achieve these two characteristics is influenced by both personal and social conditions. Honneth's recognition theory is based on a relational approach to selfdevelopment and the experience of different forms of recognition in order to form a robust self [22]. This is necessary in order to cope in today's individualized society.

In general, agency refers to the capacity to act with consideration for concerns and preferences [23]. A person's agency can be seen as a complex interaction between individual and contextual conditions. Attempts to understand this interaction emphasize various factors $[24,25]$.

Agency may be understood and investigated based on a given person's understanding of past experiences and imagined future opportunities [24-27]. In this way, it is possible to explore the person's agency in light of personal life narratives based on a context of lived experience. The narratives are also guided by the structural and cultural relationship in which they are embedded. Based on an empirical study of young adults' experiences and understandings of different periods of transition in their lives, Evans describes 
agency as something that "sees the actors as having past and imagined future possibilities, which guide and shape actions in the present, together with subjective perceptions of the structures they have to negotiate, the social landscapes that affect how they act" ([25], pp. 92-93). For example, neoliberalism can be a part of the social landscape and influence the person's agency to achieve a sense of community belonging. It emphasis on personal responsibility for one's own life path and on making the best of the opportunities society offers [28], affects the person's perceived possibilities to realize his or her desires.

Young adults negotiate their possibilities within a certain social, political, and financial context [24, 25, 29, 30]. Those who experience being outsiders in school or other mainstream settings often search for a sense of belonging in alternative environments that make them feel understood and respected. They may also search for different understandings of their feelings of subordination than those offered by the prevailing views in society. In today's society, however, such alternative ideas tend to be interpreted as individual failures, unrelated to social and economic structures [31, 32]. Moreover, the professionals whom young adults meet may not be aware of or concerned with such structures. An array of studies indicating an inner focus on 'conversation', 'alliance building', and 'working with oneself' have attained hegemony in welfare services [33-35]. Dominant moral and political views will significantly affect people's life chances and how their life stories are framed. This is especially related to citizens in marginalized positions in society.

\section{Methods}

\section{Data Development}

The present article is part of a larger qualitative study [13]. The study was carried out in a municipality in eastern Norway, with a population of around 55,000 and located close to a large city. Generally, the citizens have a high standard of living and are well educated. The unemployment rate is low, few people are on social benefits, and the local area has a generally stable social and economic situation.

Seven participants aged 18-30 were recruited through the municipal health and social services. To be included, participants had to have received services from both mental health and substance use agencies. Many young adults seeking help for their problems from these agencies have not received a psychiatric diagnosis. There were no inclusion criteria based on specific psychiatric diagnoses. The study's perspective aligns with a social-relational model of disability [36]. Interactions between the young adults and their local communities are explored and seen from the young adults' perspective. Their experiences are seen in the light of social oppression [13]. Data were collected through semi-structured in-depth interviews conducted by the first author. A semi-structured interview guide was used with open-ended questions related to the experience of belonging and conditions that promote or inhibit a sense of belonging. Participants were each interviewed twice. In the first set of interviews, they were asked to describe and elaborate upon their experiences. In the follow-up interviews, they explored new issues and elaborated upon themes derived from the findings of the first interview. These interviews were audio-recorded and were transcribed verbatim by the first author.

In the above-mentioned study aiming to explore how young adults experience challenges in belonging to their local communities, moral fumbling was one of three overarching themes from the thematic analysis [13]. Moral fumbling makes it difficult for the young adults to stand up for themselves and make demands on others. In the present article, we have re-analyzed the interviews with Anders and Evan (pseudonyms) from the main study. The two participants do not explicitly express much moral fumbling, but each of them describes a moral position that is also part of the other participant's moral negotiations.

The first interview with Anders lasted $50 \mathrm{~min}$; after a week, he was interviewed again for $1 \mathrm{~h}$ and $20 \mathrm{~min}$. The interviews with Evan lasted $50 \mathrm{~min}$ and $45 \mathrm{~min}$, respectively. The follow-up interview with Evan was carried out three and a half months after the first interview. The interviews took place at the offices of the municipal child and family services, as chosen by the participants.

\section{Analysis}

The semi structured qualitative interview data were arranged into an autobiographical narrative for each participant [37]. Our analysis of the interviews was 
primarily based upon what Riessman described as thematic narrative analysis: focusing on what is said more than the structural elements used by the participant (e.g., direct speech) or the interactions between the participant and the interviewer [38]. Central to this type of analysis is to develop a thematic plot that organizes other central themes or subplots into a coherent story [37].

The first part of the analysis was conducted as a naïve reading. Notes were taken concerning reflections on themes and patterns in the interviews. Afterward, the transcriptions were read more carefully, which included marking text judged to be central in relation to the research question. The main plots were suggested to tie the subplots together. This was done repeatedly until the suggested plots seemed to represent the central content of the text in relation to the research question. Subsequently, the focus was narrowed to investigate possible connections between different subplots (i.e., analytical bracketing: [39] pp. 28-30). The focus was on determining which events, descriptions, and words were linked to a single plot ([39], pp. 55-60). This procedure was also used for other central themes. In this way, new connections were drawn, and new ideas for the main plot and subplots emerged. To judge whether the suggested main plot seemed relevant to answer the research question, the transcriptions were read in full. The final main plot was developed by alternating between investigating the whole and investigating its parts. Finally, narratives were drawn up with the main plot as the organizing element [37]. We sought to use the participants' own words to construct the narrative. New words were added only where it was deemed necessary to produce a sufficiently coherent and reader-friendly text.

The first and second author took the lead when identifying the plots and narratives. The third author read the narratives with a critical eye and commented on aspects that seemed unclear or were described incompletely.

\section{Research Ethics}

The study was conducted in accordance with the Norwegian National Committees for Research Ethics. Ethical approval to conduct the study was granted by the Norwegian Social Science Data Services (NSD). To maintain confidentiality, the participants' statements in the presentation of the results are partially edited, and pseudonyms are used.

\section{Results}

In the following sections, we present Anders' and Evan's narratives. The heading of each narrative states the main plot.

Anders' Story-Having to Go Against Yourself to Be an Insider

Anders is ethnic Norwegian and was 21 years old at the time of the interview. One of his parents had education beyond high school. His parents divorced when he was in primary school, which led to him changing school. At the time of the interviews he had finished $10^{\text {th }}$ grade (in secondary school) five years ago, and he lived with one of his parents. He listed friends, music, and the Internet as his interests. He did not take part in any education or paid work. He has been diagnosed with ADHD and stated that he aims to reduce his use of illegal drugs. He reported that for a long time, he had felt that he was on the outside of society but wanted to be a part of society or "function in a normal way".

At school, I used to harass the teachers and wasn't afraid of showing them the finger. The more resistance I got, the more I loved it. It was awful to be scolded, but it was the only driving force. All the teachers noticed how incredibly rebellious I was, and they see how school doesn't work for a lot of kids. My hatred towards school grew continuously. Eventually, I just stayed at home-something that created a really bad result for myself. In the first year of upper secondary school, I dropped out altogether. This weakens the feeling of belonging a lot, so that when you discover cannabis, for instance, and when things start happening in your life, you'll pretty quickly be put into a category. You aren't accepted by very many people, and then it's really easy to get into the group where you are accepted.

I sought excitement and something new-a new belonging. I have had wretched friends who have nicked lots of money from me... who try to get 
you to flip out, you know. There are lots of weird rumors about me. For example, when I ask if they can change a 500 kroner note at a kioskthen, I'm met with a contemptuous laugh and questions about why I want to change money, which is none of their business. Why do people have to be so nasty all the time? Mocking others, laughing in people's faces. I feel a kind of uneasiness when I encounter such negative views but have learnt how to label them and not to care. It's mostly things like this that make my sense of belonging weaker.

Hip-hop lyrics are where I find my relationship with the world. Some of the artists refuse to stop spreading the message-have that will to fight, you know, and they come from the gutters. There is so much reality in the lyrics that I get completely swallowed up by it. Not the lyrics about selling coke on the streets or shooting black people, but seeing the unfairness and that it's really about love. Many of the artists lack love in their lives. Their mother and father have been killed, a brother has been killed. Mainly, nobody cares really. Just another black person on the streets, you know. I'm like in favor of everyone being equal and all possible justice because I know why things have worked out as they have. I want people to see such connections. But people are so busy managing on their own and don't have time to reflect on why everything is connected, and I understand that well enough-it's the way things are set up. You don't feel connected to society by trying to oppose it because as soon as you do that, you are considered either a hobo, or a druggie, or a conspiracy theorist, or a radical—whateversomething or other that's not positive. These days it's normal to have an education, a partner, work... everything's supposed to trundle along at a certain pace. There aren't many opportunities if you don't follow the 'normal' route. There is no other way out than crime. Be lucky and become a company founder, or become a musician or some kind of artist. It all seems so hopeless.

You become so dependent on society. It seems like they have total control of people. It's no use changing things from the inside either because you only get swallowed by the system. No matter if I hate the prevailing money system, no matter how much I dislike society, this is the system that exists now, and you just have to relate to it in a way that you like yourself and you can live with. I'm concerned with trying to function again in a normal way-that things will move along nicely. I am actually on my way back quite well. In a way, I'm sort of trying to go against myself a bit-trying to make friends who are a bit more normal-more A4 (more conventional)... I no longer have to cross that particular line I used to cross-it went too far then. At the same time, I don't ever suddenly want to turn around completely. I will probably always be the person I am now, on the B-side of society... I like people who are a bit quirky—not quite A4-those who dare to do some mischief or other, who are not scared of being bawled out-a bit like a monkey, but not stupid either.

When you are trapped in it politically, everything seems so meaningless. There is a place in society for everyone, but one has to find a place that is meaningful. I quit a work training scheme about two months ago. In the first six months, I felt that the job gave me a lot of purpose. I got to use my body. I did something... then, I felt it was meaningful, but as time went by, I started thinking more and more about the wages and stuff... I worked for the same low wage for a year and did work for the municipality that actually was worth a great deal... so I go to work every day and am well aware of this slavery. The municipality could have been generous and offered higher wages or another type of position. The scheme wasn't based on the possibility of you getting on further and actually starting to feel like you belong in society in a normal way. That's why I quit.

School and the social security system are set up to integrate you into the A4 society. I feel that Norway is a very correct country, and in the municipality, everything seems rather prestigious. We develop in the material world. That's my view because I've landed in the boat I've landed in and don't have that many benefits. That's why automatically, I have a negative view. I have to be able to see the negative aspects of myself as well. I am conscious of how I can improve but can't manage it-it's almost going 
against myself-it's that hopelessness always returning. But I just have to try something-just get something moving. I kind of want to get going.

Anders' narrative contains some sub-plots. One plot is resistance toward authorities and systems. Another plot related to his resistance is to be valued and understood as the person he is and what he expresses. These sub-plots may give meaning to what Anders describes as being "trapped in it politically". The main plot in Anders' narrative, having to go against yourself to be an insider is, as we see it, related to the fact that he struggles to find something that can free him from his captivity. Anders reveals that the resistance strengthens his feelings of being an outsider and restricts his opportunities of having the life he hoped for. He struggles, however, to be motivated to take part in life on the 'other side', which would mean that he had become part of a system he does not identify with. At the same time, he suggests that some of the negative aspects of life that he associated with the system may be related to his own thinking about and the distance from the 'others' in the face of negative attitudes. Anders clearly stated that he needed to 'work out something to see a future path'. Anders asked to be met with understanding rather than sanctions or stigmatization as a consequence of having broken the formal and informal rules of society; this can be understood as a wish for recognition.

\section{Evan's Story-You Have to Realize That You}

Have Problems and Try to Do Something About Them

Evan was 23 years old and is ethnic Norwegian. He describes his family as dysfunctional. He is renting a flat, and going to school at the time of the interview. He had completed upper secondary education, and he reported that friends, sports, and the Internet were some of his hobbies. He said that he now controlled his substance use. Periodically, he is depressed and isolates himself socially. He described his experiences trying to take on a new position in society in the following narrative:

Sometimes one gets off to a bad start... You know, some people have very good role models or parents who look after you well. My parents were more passive in that way, actually. There was a lot of scolding and shouting - not so much concern with showing how you can do things. I ended up in awkward situations because I didn't know how to behave. That's probably part of the reasons why it was harder for me to feel included. I do remember secondary school... There was a real hierarchy. You have the biggest bully, and then you have the ones who are bullied. When you are being bullied and are insecure, then you project your insecurity onto others again and treat others the way you yourself have been treated. I have been insecure and am deeply ashamed of how I have treated some people. Instead, I could just have risen above it all. It was kind of up to me to figure things out... Then, things take a bit longer. Meanwhile, you put yourself in the position of being more exposed to things like drugs... and I wasn't really in the healthiest company. The environment isn't the reason, but it's really easy to get influenced by it. You feel a sense of belonging, and then you do stuff that makes you feel included. Birds of a feather flock together; that's the way it is.

I've gone through a period of self-examination and come to realize that the person who has the most problems with all these issues is, in fact, myself. If you think life is shit, you're the one who thinks that, it's not other people trying to make it like that. As you manage to actually see the reasons behind something, then you can find a solution to how to get out of it-buck the trend. When you realize that you are the cause of what's negative in your life, you kind of have to work with what you have. The world is filled with a good combination of skills and coincidences. I'm actually a huge champion of Darwin and the 'survival of the fittest': if you can manage to adjust well to a social situation, of course, you feel a sense of belonging. It's a game that is... well... a competition for the most outgoing and socially skilled. This is something you don't understand at a young age. You have to practice to achieve what is needed.

I have chosen to work from the point of view that most of what I do can be corrected and improved upon. You have to be a bit aware and consider that you are most often not right. Not the most positive outlook on life, but realistic. Everything 
is about getting something that works... If it works, there is no point in fixing it. It is also important to know where you won't feel as if you belong. I don't identify with... people who would have prevented me from achieving my goals. I am well aware of not really being one of the most socially skilled or outgoing people. I know I'm not the most fun person to be with. That's why I don't like people who are very like me. The people I hang around now are pretty bright. I think they are cool dudes who I like being with, feeling little resistance when I'm with them, and they bring out the best in me. I want people who are different but with similar interests and things. I find it easy to talk to them, and in that way, find a sense of belonging. I want to meet new people... yes... it seems like it's through new people you manage to develop further.

Now I have quite a few qualifications helping me to integrate into a new environment. Throughout the last three years, I have learned what it means to be part of something. I know very well what it means. The only difference is your attitude, which is easy to change. At the same time, it is ridiculously easy to feel sorry for yourself and take on a position as a victim. I have been depressive a lot, but it is... in fact, a condition of the mind you've put yourself in because of feeling like a victim... That's how I choose to look at it. I don't believe in depression. In social settings, you cannot just take... You have to contribute to the community. In order for me to feel togetherness with a person, I have to include myself... You have to hang out with that person, whether it is to go on a bender or play PlayStation and smoke together. You've got to suggest cool stuff. Life is often a long, boring affair, so it's all about making the best of it.

I really don't like to be such a sponger on society. What I receive, I will, at some stage, give back. I would like to be of use to people and able to pay my bills and do administrative tasks, which is part of life, actually. Everything could have been better, but you learn to be content with what you have. Why shouldn't you be content with how your life is? Everything is relative anyway so... No, actually there are small things, you know... I'm fed up to the teeth with waiting for simple stuff-not about belonging, but small irritating bureaucratic things-that's all.

One sub-plot in Evan's narrative is to understand how he experiences the workings of the world around him, both the close and the more distant world. Two other sub-plots are knowledge of what is required to integrate and to control himself by setting realistic goals. The main plot, you have to realize that you have problems and try to do something about them, is related to recognizing his problems in relation to how the world functions, and as best as he can manage, to try to adapt to the rules in areas of life he is, or wants to be, part of. Evan stated that he had broken off relationships that did not contribute to the creation of constructive forces within him, including relationships with his family and with the environment is which he grew up. His use of expressions, such as the statements that it is "ridiculously simple to change your focus" and that one should not "take on a victim position," may be viewed as expressions of strong normative engagement. Evan uses the term "realistic" about strategies that help him to achieve what he wants and to realize how the world works. Evan conveyed the perspective that individuals have the main responsibility to find a suitable place in society. To a large degree, he emphasizes peoples' abilities to use selfreflection to discover which values and objectives they consider important to reach for in life. Whether or not an individual has the opportunity to use this ability depends on whether one's goals are realistic or not.

\section{Discussion}

In their narratives, Anders and Evan presented different experiences and descriptions of their own and others' contributions to their sense of community belonging. In the following, we will discuss how the two young men describe their opportunities for community belonging in relation to how they negotiate meaning of their past experiences and structural barriers. We will also reflect on implications that the young persons' descriptions might have for the professional work of supporting young adults with co-occurring problems in achieving a sense of belonging. 
Negotiating Future Opportunities in Light of Past Experiences

The two narratives differed in their emphasis on the individual's responsibility to acquire a sense of belonging. Both Anders and Evan realized that their dissatisfaction with their situations could color their perceptions of the world. However, they imparted differing perspectives regarding whether the reasons for their dissatisfaction were legitimate and whether society ought to consider impactful experiences in adolescence when forming opportunities for belonging.

Honneth emphasizes that people are dependent on receiving different forms of recognition to fulfill their potential [22]. Recognition is considered as a necessary condition to develop a positive relationship with oneself, which is seen as decisive for one's capacity to assert oneself in modern society. Honneth links social resistance to a need for recognition that is not being met. Different actors in society may contribute to a lack of agency and experiences of alienation when they do not recognize the value of the individual. Honneth's types of recognition point to different spheres in society and arenas where such violations may occur.

Anders's exercise agency in relationships to achieve a sense of community belonging may be linked to the fact that he will not let go of his childhood experiences of not being understood and met with recognition. This form of misrecognition can be derived from the cultural sphere of society and value-hierarchy that awards people unequal levels of status based on a valuation of their particular skills and traits [22]. This is also the case when Anders experienced stigmatization while encountering other citizens, he experienced a lack of social acceptance. Lack of such recognition will generally make it harder for a person to value her or his own qualities and accomplishments. Hanne Thommesen's [40] study of young adults with co-occurring problems supports this:

A consistent characteristic of these young people's stories is that they have problems defining themselves and envisioning a meaningful future. It appears they have problems believing that there is a place for them in society and that their existence matters. They all express a strong wish to contribute to society, but at the same time say that in the course of their lives they have had ample evidence that what they have to offer is not seen as valuable. (p. 99) (our translation).

Anders had no higher education, and it was his experience that many people around him thought he should acquire more skills to increase his job opportunities. He found that education was the norm in society. He was also offered a work training scheme that did not help him "to feel like you belong in society in a normal way". Anders suggested that society should compensate for the unfairness that 'outsiders' have encountered by providing services that offer more generous job opportunities and offer more than 'slave pay'.

The justice sphere of recognition comprises society's more anonymous and abstract signs of social respect. The modern justice system is developed to handle universal or common characteristics. According to Honneth, such universal respect contributes to the development of self-respect and the opportunity to set goals for one's own life. Anders argues that all people need to be treated equally. He has experiences of not being listened to. This serves as a reminder of this recognition sphere.

Honneth noted that human beings must receive recognition through emotional ties to primary persons to trust their own needs, impulses and perceptions [22]. Different studies have pointed to the notion that not having been valued by adults while growing up contributes to marginalization and issues with finding one's place in society [14]. Neither Anders nor Evan emphasized close relationships in adolescence during the interviews. Anders, however, explained that hiphop artists' critical views of society had resulted from a lack of love in their lives. Evan mentioned that he had problematic family relations, but he did not want to expand any further because, in his view, it was of little constructive value. Evan's narrative left no room for self-pity. Although an explicit desire for recognition was not a central element of his narrative of his search for community belonging, he noted the importance of being useful; this could be understood as a wish for social recognition. However, this also indicates that Evan wished to gain approval by deserving it, rather than by setting demands. He seems to emphasize the need to change and adapt to the demands of social life. 
Evan emphasized that it was largely up to him to experience community belonging. However, he explained that it is important to have access to social environments to achieve this. The research literature points out that being in a new social environment and adopting new cultural norms may be one of the biggest barriers when changing substance use habits. In particular, this applies to individuals who have been socialized to reject society's ideals of conformity $[41,42]$. Thommesen [40] describes young adults with co-occurring problems who, like Anders, find it necessary to break with old friends and their past in order to become part of society. This process is described as lonely and a denial of the past (p. 67). Evan's narrative, however, could be considered to support the view that an individual's abilities to creatively seek and focus on future opportunities contribute to aspect of their own agency [43]. This can, to a certain extent, override old habits that influence thoughts and behavior [26]. Therefore, the ability to find and, if needed, get help to seek out a future path that is both possible and desirable is an important resource on the road to finding a sense of community belonging. Separating from a problematic past becomes easier when one finds something to value and attempt to achieve [44]. Evan emphasized that, in the search for a possible future path, one must use what one already has as a starting point and then see what one may achieve using this resource. Anders, on the other hand, seemed to have difficulty accepting this idea.

The two narratives emphasize a possible path to achieve community belonging in the future. Creating such a path should therefore be a central task in health and social services. Anders' narrative suggests that his future prospects may improve if he is met with interest and recognition. Honneth's recognition theory offers some direction regarding ways that professionals can contribute to meeting young adults' needs for recognition [45-47]. Numerous studies demonstrate that young adults in marginal positions need to be met with respect and recognition and to experience that someone is there to support them [for example 4, 14, 45]. The key importance of recognition is also supported by the literature on people with mental health and substance use problems, which emphasizes building a positive identity outside one's problems in order to achieve a meaningful social connection [47, 49]. Getting help to create a self-narrative based on valuing personal characteristics is one way to support this goal $[27,50,51]$.

Based on Evan's narrative, the role of professionals is first and foremost to help young adults to have a realistic understanding of themselves in relation to how society works and to have realistic expectations of life in line with this understanding. However, one can ask whether such a strategy involves letting young people expect too little from their lives [51, 52].

\section{Negotiating Belonging When Facing Structural Barriers}

Both Anders and Evan felt they were not in a position to change the structural conditions that limited their opportunity to experience community belonging, and each of them dealt with the situation in a different way.

Anders pointed to the idea that the ruling economic system is an enemy that is impossible to beat. His resistance is toward the lack of understanding and value granted by society to 'outsiders' like him. Anders' dilemma was reflected by his resistance to society from the position of an underdog, which undermined any opportunities for him to make it in social life. Even if Anders related actively to society by protesting against the conditions he saw as unfair, he would still have little power to change these conditions. The authorities that represented and supported this system further contributed to his feelings of being left out (i.e., on the outside). This included professionals and others who had the responsibility to help him and encourage his feelings of inclusion and belonging.

The ruling economic system, as Anders described it, is strongly affiliated with neoliberalism. In this system, market forces rule the development of society to the largest possible extent, forcing the individual to fall into line [28]. Welfare services are also integral parts of neoliberalism [35]. Previous studies have described a therapeutic culture as common in health and social services and society in general. Such a culture contributes to creating self-disciplined, responsible, and efficient people. The individual is expected by society to view her/himself through psychological prisms, and then learn to control any emotional or physical problems [34, 53, 54].

The realism that Evan described as necessary to achieve a desired place in society could be said to precisely reflect the prevailing societal norms. There 
are references to a therapeutic culture present in Evan's emphasis on self-reflection. In his interviews, he used psychoanalytical terms [55], for example "project your insecurity". Evan also claimed that depression can be overcome by the power of thought. The idea of self-adequacy can be linked to neoliberalism, which emphasizes free-market competition and the individual's competent participation in the market. Social participation thus becomes competition-based, and requires individuals to be responsible in their choices for such competition. Evan's support of Darwinian "survival of the fittest" runs parallel to some neoliberalist thoughts. The mechanisms of the market represent a sort of 'natural social order'. Moral virtue is linked to a person's ability to be a competent participant in the market. Individuals are responsible for their own 'free choices', and demanding assistance from the state when mistakes are made testifies to failing personal development and morals. Neoliberalism emphasizes the freedom of the competent, rather than traditional liberal demands for democracy, human rights, and equal freedom [28]. Neoliberalism does not have space for the 'romantic' or 'idealistic' demands that one might accuse Honneth's recognition theory of having. One must try, according to one's abilities, to adapt to current norms and rules; that is the reality. Resisting, as Anders did, could be seen as naïve and useless.

The two narratives are similar in that they both describe young adults who must deal with certain mechanisms creating inequality in order to find a sense of community belonging. This raises questions regarding how service providers relate to such mechanisms and what kinds of knowledge they may have about these mechanisms [51, 56, 57]. The mechanisms can be expressed as practices within health and social services, and they often become implicit parts of service providers' bases for evaluation [35, 58, 59]. Waldegrave [60] argued that practitioners and politicians often sweep challenges linked to social differences under the carpet by making people satisfied with the status quo rather than addressing underlying causes. The professionals may not be able to alter the economic system, but yet they need to possess knowledge of systems and rights to become 'lawyers' for young adult service-users. The exercise of such a role may represent an important recognition regarding practice [61].
Limitations and Strengths

A narrative analysis enabled rich descriptions of the two participants' experiences and their places in society. The analysis provided a more complex picture of the dilemmas faced by each individual in relation to their strategies for creating a sense of belonging in society, compared to more traditional methods of qualitative thematic analysis.

As with any other qualitative study, several issues affect the transferability of the results. Just as important as transferability is how the narrative approach inspires reflections on highlighting various perspectives. The decision not to focus on the co-occurring problems and psychiatric diagnoses in the interviews with the young adults can make it difficult to relate the results to specific co-occurring problems. The two participants were male. Female participants could have highlighted other factors that could improve their life situation [62]. The participants were in their early $20 \mathrm{~s}$. This is a period of life when a number of changes take place, such as moral development [63]. Older participants would probably have led to different results. The participants grew up and lived in a 'rich' municipality with generally high material and social life expectations among the citizens. An upbringing in a more deprived area could have resulted in other narratives. Despite the fact that the results may be conditioned in various ways, they also address moral tension that other marginalized young adults can relate to $[4,15,64]$. The results allow for a deeper understanding of moral issues.

The interviewer may have been viewed as a representative of 'mainstream' society by the participants. This may have led them to distance themselves from 'subcultural values' or create a defense of such values. However, narratives that relate to presumed dominant societal values and norms could shed light on the answer to the present research question.

\section{Conclusions}

The two narratives offered a normative engagement from two different perspectives: (1) Anders wished to be seen and understood in relation to his marginal position, whereas (2) Evan did not, in any way, wish to be seen as a victim. Both positions may find support amongst other young adults with co-occurring 
problems, society in general, health and social services, researchers, and normative theories. This underlines that values are at stake.

The manner in which health and social services related to the normative tension expressed by the two narratives, could be crucial in understanding and finding solutions to the challenges faced by young adults with co-occurring problems that are seeking to avoid experiences of being outsiders. In order to support young adults in marginalised situations in relation to identity questions and finding their place in society, service providers' understanding of situations can be of crucial importance to how the young adults understand 'being outsiders', how they create their own self-narrative, and which direction they may choose to follow in their lives. Normative experiences and reasonings among young persons that are not taken seriously by professionals may become barriers to supporting young adults to experience belonging. The present article shows that young adults with cooccurring problems should be offered support to position and negotiate their experiences into a larger social context. This implies that professionals should not only look for pragmatic solutions to promote sense of community belonging. Rights and social justice perspectives should also be in their toolbox.

Funding Open access funding provided by University Of South-Eastern Norway.

Open Access This article is licensed under a Creative Commons Attribution 4.0 International License, which permits use, sharing, adaptation, distribution and reproduction in any medium or format, as long as you give appropriate credit to the original author(s) and the source, provide a link to the Creative Commons licence, and indicate if changes were made. The images or other third party material in this article are included in the article's Creative Commons licence, unless indicated otherwise in a credit line to the material. If material is not included in the article's Creative Commons licence and your intended use is not permitted by statutory regulation or exceeds the permitted use, you will need to obtain permission directly from the copyright holder. To view a copy of this licence, visit http://creativecommons.org/licenses/by/4.0/.

\section{References}

1. May V. Self, belonging and social change. Sociol. 2011;45(3):363-78.
2. Evjen R, Kielland KB, Øiern T. Dobbelt opp. Om psykiske lidelser og rusmisbruk (Twice the problem. Mental disorders and substance abuse). Oslo: Universitetsforlaget; 2012.

3. Morisano D, Babor TF, Robaina KA. Co-occurrence of substance disorders with other psychiatric disorders: implications for treatment services. Nord Stud Alcohol Drugs. 2014;31(1):5-25.

4. Thommesen H. Hverdagsliv, selvforståelse og dobbeltdiagnose: om mennesker med uvanlige erfaringer (Everyday life, self-esteem and dual diagnosis: about people with unusual expiries). Doctoral dissertation. Bodø: Bod $\varnothing$ University College; 2008.

5. Helsedirektoratet. Nasjonal faglig retningslinje for utredning, behandling og oppfølging av personer med samtidig ruslidelse og psykisk lidelse-ROP-lidelser (National professional guideline for the assessment, treatment and follow-up of people with co-occurring substance abuse and mental disorder). Oslo: Helsedirektoratet [Norwegian Directorate of Health]; 2012.

6. De Ruysscher C, Vandevelde S, Vanderplasschen W, De Maeyer J, Vanheule S. The concept of recovery as experienced by persons with dual diagnosis: a systematic review of qualitative research from a first-person perspective. J Dual Diagn. 2017;13:264-79.

7. Ness O, Borg M, Davidson L. Facilitators and barriers in dual recovery: a literature review of first person perspectives. Adv Dual Diagn. 2014;7(3):107-17.

8. Barnett H, Lapsley H: Journeys of despair, journeys of hope. Young adults talk about severe mental distress, mental health services and recovery. Wellington: Mental Health Commission; 2006.

9. Rayner S, Thielking M, Lough R. A new paradigm of youth recovery: implications for youth mental health service provision. Aust J Psychol. 2018;70(4):330-40.

10. Lister R, Smith N, Middelton S, Cox L. Young people talk about citizenship: empirical perspectives on theoretical and political debates. Citizenship Stud. 2003;7(2):235-53.

11. Wood EB. Youth studies, citizenship and transitions: towards a new research agenda. J Youth Stud. 2017;20(9):1176-90.

12. Mitchell DP, Betts A, Epling M. Youth employment, mental health and substance misuse: a challenge to mental health services. J Psychiatric Ment Health Nurs. 2002;63(9):191-8.

13. Semb R, Tjora A, Borg B. Communal invalidation of young adults with co-occurring substance abuse and mental health issues. Disabil Soc. 2019;34(6):926-44

14. Lo C, Olsen T, Anvik CH. Mellom linjene? En kunnskapsstatus om ungdom med sammensatte behov for offentlige velferdstjenester (Between the lines? A state of knowledge about youth with complex needs for public welfare services). Bodø: The Nordland Research Institute; 2016.

15. Skogens L, von Greiff N, Ekström JE. Positiva förändringsprocesser bland unga vuxna i öppenvård (positive processes of change among young adults in outpatient care). Socialvetenskaplig tidskrift. 2017;24(1):39-57.

16. Sommer M, Ness O, Borg M. Helpful support to promote participation in school and work: subjective experiences of people with mental health problems - a literature review. Soc Work Ment Health. 2017;16(3):346-66. 
17. Hacking S, Bates P. The Inclusion Web: a tool for personcentred planning and service evaluation. Ment Health Rev J. 2008;13:4-15.

18. Hagerty BM, Lynch-Sauer J, Patusky KL, Bouwsema M, Collier P. Sense of belonging: a vital mental health concept. Arch Psychiatr Nurs. 1992;6(3):172-7.

19. Padgett DK, Henwood B, Abrams C, Davis A. Engagement and retention in services among formerly homeless adults with co-occurring mental illness and substance abuse: voices from the margins. Psychiatr Rehabil J. 2008;31(3):226-33.

20. Leahy D, Schaffalitzky E, Armstrong C, Bury G, Davis R, Cussen-Murphy P, Davis R, Dooley B, Gavin B, Keane R, Keenan E, Latham L, Meagher D, McGorry P, McNicholas F, O'Connor R, O'Dea E, O'Keane V, O'Toole TP, Reilly E, Ryan P, Sanci L, Smyth BP, Cullen W. Primary care and youth mental health in Ireland: qualitative study in deprived urban areas. BMC Fam Pract. 2013;14(1):194.

21. Stein KF, Connors EH, Chambers KL, Thomas CL, Stephan $\mathrm{SH}$. Youth, caregiver, and staff perspectives on an initiative to promote success of emerging adults with emotional and behavioral disabilities. J Behav Health Serv Res. 2014;43(4):582-96.

22. Honneth A. Kamp om anerkjennelse (struggle for recognition). Oslo: Pax Forlag; 2007.

23. Archer M. The ontological status of subjectivity. In: Lawson C, Latsis J, Martins N, editors. Contributions to social ontology. London: Routledge; 2007. p. 17-31.

24. Evans K. Taking control of their lives? Agency in young adult transitions in England and the New Germany. J Youth Stud. 2002;5(3):245-69.

25. Evans K. Concepts of bounded agency in education, work and the personal lives of young adults. Int $\mathrm{J}$ Psychol. 2007;42:85-93.

26. Emirbayer M, Mische A. What is agency? Am J Sociol. 1998;103(4):962-1023.

27. McConnell D. Narrative self-constitution and vulnerability to co-authoring. Theor Med Bioeth. 2016;37(1):29-43.

28. Thorsen E. The neoliberal challenge: what is neoliberalism? Contemp Read Law Soc Justice. 2010;2(2):188-214.

29. Furlong A. Revisiting transitional metaphors: reproducing inequalities under the conditions of late modernity. J Educ Work. 2009;22(5):343-53.

30. Wyn J, White R. Young people, social problems and Australian youth studies. J Youth Stud. 1998;1(1):23-38.

31. Lalander P, Sernhede O. Social mobilization or street crimes: two strategies among young urban outcasts in temporary Sweden. Educare. 2011;2:99-121.

32. Johansson T, Lalander P. Doing resistance-youth and changing theories of resistance. J Youth Stud. 2012;15(8):1078-88.

33. Beresford P, Boxall K. Service users, social work education and knowledge for social work practice. Soc Work Edu. 2012;31(2):155-67.

34. Kroken R, Madsen OJ. Forvaltning av makt og moral i velferdsstaten. Fra sosialt arbeid til arbeid med seg selv? Oslo: Gyldendal forlag; 2016.

35. Mik-Meyer N, Villadsen K. Power and welfare: understanding citizens' encounters with state welfare. New York: Routledge; 2013.
36. Thomas C. Sociologies of disability and illness: contested ideas in disability studies and medical sociology. Basingstoke: Palgrave Macmillan; 2007.

37. Polkinghorne DE. Narrative configuration in qualitative analysis. Int J Qual Stud Edu. 1995;8(1):8-25.

38. Riessman CK. Narrativ analyse i samfundsvidenskaberne [Narrative analysis in the social sciences]. In: Järvinen M, Mik-Meyer N, editors. Kvalitativ analyse: syv traditioner. København: Hans Reitzels Forlag; 2017. p. 235-72.

39. Gubrium JF, Holstein JA. Analysing narrative reality. Los Angeles: Saga; 2009.

40. Thommesen H. Hverdagsliv med psykiske og rusrelaterte problemer. Oslo: Gyldendal Akademisk; 2012.

41. Best D, Beckwith M, Haslam C, Haslam AS, Jetten J, Mawson E, Lubman DI. Overcoming alcohol and other drug addiction as a process of social identity transition: The Social Identity Model of Recovery (SIMOR). Addict Res Theory. 2016;24(2):111-23.

42. Cloud W, Granfield R. Conceptualizing recovery capital: expansion of a theoretical construct. Subst Use Misuse. 2008;43:1971-86.

43. Bandura A. A sociocognitive analysis of substance abuse: an agentic perspective. Psychol Sci. 1999;10:214-7.

44. Bengtsson TT, Mølholt AK. Creation of belonging and nonbelonging in the temporal narratives of young people transitioning out of care in Denmark. Nordic Soc Work Res. 2018;8(1):54-64.

45. Marthinsen E, Skjefstad N. Recognition as a virtue in social work practice. Eur J Soc Work. 2011;14(2):195-212.

46. Petersen A, Willig R. Work and recognition: reviewing new forms of pathological developments. Acta Sociol. 2004;47(4):338-50.

47. Klyve A. Sinte, unge, villfarne menn (Angry, young, misguided men). Bergen: Fagbokforlaget; 2016.

48. Davidson L, White W. The concept of recovery as an organizing principle for integrating mental health and addiction services. J Behav Health Serv Res. 2007;34(2):109-20.

49. Rowe M, Davidson L. Recovering citizenship. Isr J Psychiatry Rel Sci. 2016;53(1):14-21.

50. Chorlton E, Smith I. Understanding how people with mental health difficulties experience substance use. Subs Use Misuse. 2016;51(3):318-29.

51. Grant A, Leigh-Phippard H, Short NP. Re-storying narrative identity: a dialogical study of mental health recovery and survival. J Psychiatr Ment Health Nurs. 2015;22:278-86.

52. Brekke E, Lien L, Nysveen K, Biong S. Dilemmas in recovery-oriented practice to support people with co-occurring mental health and substance use disorders. Int $\mathbf{J}$ Ment Health Syst. 2018;12(30):1-9.

53. Brunila K. The rise of the survival discourse in an era of therapisation and neoliberalism. Educ Inq. 2014;5(1):7-23.

54. Wright K. Theorizing therapeutic culture: past influences, future directions. J Sociol. 2008;44:321-36.

55. Bateman A, Holmes J. Introduction to psychoanalysis. London: Routledge; 1995.

56. Blomberg H, Kallio J, Kroll C, Niemelä M. What explains frontline workers' views on poverty? A comparison of three types of welfare sector institutions. Int $\mathrm{J}$ Soc Welf. 2015;24(4):324-34. 
57. Clayton A, Miller R, Gambino M, Rowe M, Ponce AN. Structural barriers to citizenship: a mental health provider perspective. Community Ment Health J. 2020;56:32-41.

58. Hasenfeld $\mathrm{Y}$. The attributes of human service organizations. In: Yeheskel $\mathrm{H}$, editor. Human services as complex organizations. Los Angeles: Sage; 2010. p. 9-32.

59. Järvinen M, Mik-Meyer N. At skabe en klient. Institutionelle identiteter $\mathrm{i}$ socialt arbejde (To create a client. Institutional identities in social work). Copenhagen: Hans Reitzel; 2003.

60. Waldegrave C. Cultural, gender, and socioeconomic contexts in therapeutic and social policy work. Fam Process. 2009;43(1):85-101.

61. Ness O, Borg M, Semb R, Karlsson B. "Walking alongside:" collaborative practices in mental health and substance use care. Int J Ment Health Syst. 2014;8(55):1-8.
62. von Greiff N, Skogens L. Positive processes of change among male and female clients treated for alcohol and/or drug problems. J Soc Work. 2017;17(2):186-206.

63. Hoare C. Three missing dimensions in contemporary studies of identity: the unconscious, negative attributes, and society. J Theor Philos Psychol. 2013;33:51-67.

64. Anvik CH, Waldahl RH. Excluded youth in Iceland, the Faroe Islands and Norway. Nordisk Välfärdsforskning/Nord Welf Res. 2017;2(1):7-29.

\section{Publisher's Note}

Springer Nature remains neutral with regard to jurisdictional claims in published maps and institutional affiliations. 